\title{
Archives Of Breast

\section{Serum Inflammation Biomarkers and Micronutrient Levels in Nigerian Breast Cancer Patients with Different Hormonal Immunohistochemistry Status}

Ganiyu Olatunbosun Arinola*a, Fabian Victory Edema ${ }^{a}$, Abayomi Benjamin Odetunde ${ }^{\mathrm{b}}$, Christopher Olusola Olopade ${ }^{c}$, Olufunmilayo Ibironke Olopade ${ }^{d}$

aDepartment of Immunology, College of Medicine, University of Ibadan, Ibadan, Nigeria

bInstitute of Advanced Medical Research (IAMRAT), College of Medicine, University of Ibadan, Ibadan, Nigeria

'Department of Medicine and the Center for Global Health, University of Chicago, Chicago, USA

${ }^{d}$ Center for Clinical Cancer Genetics and the Center for Global Health, University of Chicago, Chicago, USA

ARTICLE INFO

Received:

02 June 2021

Revised:

25 July 2021

Accepted:

26 July 2021

\section{ABSTRACT}

Keywords:

Cytokines,

breast cancer,

inflammation,

methylation,

micronutrients

Background: The importance and relevance of serum inflammation biomarkers and DNA methylation-dependent micronutrients in breast tumorigenesis is gaining wider acceptance. However, the association of serum inflammation biomarkers and micronutrient status with expression of estrogen receptors (ER), progesterone receptors (PR) and human epidermal growth factor receptor-2 (HER-2) by the tumor has not been investigated in Nigerian breast cancer patients. The objective of this study was to determine the levels of serum biomarkers of inflammation [Homocysteine, Nitric Oxide (NO), Hydrogen peroxide (H2O2), Myeloperoxidase (MPO), Tumor necrosis factor alpha (TNF- $\alpha$ ), Interleukins 6 and 8 (IL-6 and IL-8)] and DNA methylationdependent micronutrients [Zinc (Zn), Folic acid, Vitamin B6 and B12] in breast cancer patients with different hormone receptors (ER, PR and HER-2).

Methods: One hundred and fifteen women ( 80 with breast cancer and 35 controls) were randomly recruited for this study. Serum levels of homocysteine, folic acid, vitamins B6, vitamin B12, TNF$\alpha$, IL-6 and IL-8) were analyzed using ELISA, while the levels of NO, MPO, $\mathrm{H}_{2} \mathrm{O}_{2}$ and $\mathrm{Zn}$ were determined using spectrophotometer in patients with breast cancer and control subjects without breast cancer as well as breast cancer patients with ER, PR and HER-2 expression were determined.

Results: The results showed that mean serum levels of IL-6 ( $\mathrm{P}=0.002)$, IL-8 $(\mathrm{P}=0.018)$ and H2O2 $(\mathrm{P}=0.000)$ were significantly increased while TNF- $\alpha(\mathrm{P}=0.014)$ and NO levels $(\mathrm{P}=0.044)$ were significantly decreased in breast cancer patients compared to healthy controls. However, there were no statistically significant differences in the levels of Zn, homocysteine, Vitamin B6, Vitamin B12 and MPO in breast cancer patients and controls. Furthermore, the levels of serum inflammatory biomarkers and methylation-dependent micronutrients were similar in breast cancer patients with HER-2, ER and PR expression.

Conclusion: Systemic inflammation exists in breast cancer patients but the inflammation biomarkers and methylation-dependent micronutrients did not differ among breast cancer patients with PR, ER and HER-2 expression.

Copyright $(C$ 2021. This is an open-access article distributed under the terms of the Creative Commons Attribution-Non-Commercial 4.0 International License which permits copy and redistribution of the material in any medium or format or adapt, remix, transform, and build upon the material for any purpose, except for commercial purposes.

\section{INTRODUCTION}

Globally, breast cancer is the most commonly diagnosed cancer in women, ${ }^{1}$ and while progress has been made over the last decades in understanding the biology of breast cancer, the mechanisms for growth

\footnotetext{
*Address for correspondence:

Ganiyu Olatunbosun Arinola, MD

Department of Immunology, College of Medicine,

University of Ibadan, Nigeria

Tel: +234 802345 1520, +2348098121520

Email: drogarinola64@gmail.com
}

and progression of breast cancer with different hormonal phenotypes and therapeutic resistance are still not fully understood. ${ }^{2,} 3$ Inflammation is an important factor in carcinogenesis; hence, the use of non-steroidal anti-inflammatory drugs such as aspirin in cancer prevention adjuvant therapy, ${ }^{4}, 5$ and micronutrients as supplements is suggested. ${ }^{6}$ There is evidence that DNA methylation and its associated micronutrients influence incidence of cancers through regulation of inflammatory genes and that the tumor 
cells produce proinflammatory factors that encourage chronic inflammation and tumor growth. ${ }^{7,8}$

Studies associating circulating homocysteine with overall breast cancer risk are limited and inconsistent. ${ }^{9}$ Homocysteine is associated with oxidative damage and metabolic disorders which may lead to carcinogenesis. It is trans-sulfurated to cysteine or remethylated to methionine using cystathionine $\beta$-synthase with vitamin B6 and methionine synthase with vitamin B12 plus folate, respectively..$^{10}$ In vitro studies have shown that homocysteine levels were positively associated with proliferation rates of cells in several tumors, including breast cancer. ${ }^{11,12}$ Similar associations have been observed with oxidative damage to cells apart from breast cancer cells. ${ }^{13,}{ }^{14}$ One case-control study reported a positive association between homocysteine levels and breast cancer risk, ${ }^{15}$ whereas another cohort study did not observe such association. ${ }^{9}$

Folate, vitamin B6, Zn and vitamin B12 are important in cancer prevention by upholding DNA integrity and regulation of gene expression. ${ }^{16,} 17$ Observational studies have suggested an inverse association between high intake or blood levels of folate, vitamin B6, and vitamin B12 and increased risk of cancer, particularly colorectal and breast cancers. ${ }^{18-21}$ Zinc activates inflammasome, ${ }^{22}$ induces IL-1 $\beta$ secretion by macrophages, ${ }^{23}$ reduces IL- 6 and TNF- $\alpha$ in human monocytes, ${ }^{24}$ and neutralizes generation of reactive oxygen species (ROS). Two case-control studies demonstrated statistically significant inverse associations between serum $\mathrm{Zn}$ exposure and breast cancer risk. ${ }^{25,}{ }^{26}$ However, two nested case-control studies reported no association between zinc in benign breast tissue and breast cancer risk. ${ }^{27,}{ }^{28}$ Another case-control study also found no difference in plasma level of zinc between breast cancer cases and controls. ${ }^{29}$ Thus, interlinkage of Zn, vitamin B6, B12, folate and homocysteine metabolism seems essential for carcinogenesis but the results are inconsistent.

The importance of steroid hormone receptors to the biology of breast cancer was recognized when human breast cancers were shown to be dependent on estrogen and/or progesterone through their receptors for growth. ${ }^{30}$ Breast cancer cells may or may not have estrogen receptor (ER), progesterone receptor (PR), and Human Epidermal Growth Factor Receptor 2 (HER-2). These receptor types have been found to determine breast cancer aggressiveness, treatment and prognosis ${ }^{31,32}$ but the basis of this is not yet fully elucidated.

Metastasis involves cellular elements that secrete humoral products, which modulate the behavior of tumor cells in the micro-environment. ${ }^{33,34}$ Hence, the presence of hypoxia and abundance of cytokines (Colony Stimulating Factor-1, TNF- $\alpha$, IFN- $\gamma$ and MIF in the tumor determines the macrophage subtypes (M1 and M2), ${ }^{35,36}$ which affect the clinical course of the tumor. M1 macrophages are 'primed' by the cytokine IFN- $\gamma$ for activation either by TNF- $\alpha$ or (and more importantly) by activation of toll-like receptors. ${ }^{37}$ Activated M1 macrophages secrete proinflammatory cytokines such as interferons and interleukins (IL-12, IL-23), ${ }^{36}$ generate toxic oxygen species and activate inducible NO synthase (iNOS) gene to produce nitric oxide (NO). Nitric oxide is an intermediate reactive oxygen species and prolonged exposure to NO results in DNA damage that is linked to cancer development. ${ }^{37}$ M2 macrophages are activated by cytokines or by immune complexes to induce T-helper 2 immune responses.

Overall, micronutrients and other inflammation factors play important roles in tumor progression. Therefore, knowledge of functions and levels of biomarkers of inflammation, and micronutrients involved in tumorigenesis could provide better understanding of tumor development, prevention and immunotherapy. This study explored the relationship between pro-inflammation factors (IL-6, IL-8, TNF$\alpha, \mathrm{NO}, \mathrm{MPO}$ and $\mathrm{H}_{2} \mathrm{O}_{2}$ ) and DNA methylationdependent micronutrients ( $\mathrm{Zn}$, folate, vitamin B6, B12 and homocysteine) in breast cancer patients compared with controls in different breast cancer hormone subtypes in Nigerian women.

These markers (pro-inflammation factors and DNA methylation-dependent micronutrients) were evaluated in the participants because they were directly linked with breast cancer immune-pathology and progression.

\section{METHODS}

Subjects

Approval for the study was obtained from the ethics committee of UI/UCH, Ibadan. After obtaining informed consent, eighty women with breast cancer who attended the University Teaching Hospital Ibadan, Oyo State, in Nigeria were recruited between March 2016 and June 2019. The mean age of women was $57.9 \pm 11.1$ years. Breast cancer patients who received any therapy prior to diagnosis (surgery/radiotherapy/chemotherapy) were excluded. Patients who presented with other malignancies, advanced organ failure or active infection were also excluded. The diagnosis of breast cancer was confirmed by histopathological and immunohistochemistry examination of the tumor tissue samples. Thirty-five healthy age-matched female

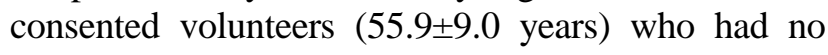
history or clinical evidence of breast problem or cancer drawn from the Hospital and University communities were selected as healthy controls. Confounding factors such as age of menarche, ethnicity, age of first birth and 
parity were not taken into consideration during the study. However, smokers, hormone and alcohol users, and obese participants were excluded. All participants on compulsory medications or on food supplements were also excluded. Blood samples collected from breast cancer patients before treatment and in the healthy controls were allowed to clot, centrifuged at $8000 \mathrm{rpm}$ for 10 minutes, serum separated and stored at $-80^{\circ} \mathrm{C}$ until analyzed.

\section{Serum IL-6, IL-8 and TNF- $\alpha$ assays}

The procedure followed the manufacturer's (ABCAM USA) instructions as previously described. ${ }^{38}$ All reagents were brought to room temperature (18$25^{\circ} \mathrm{C}$ ) prior to use. Up to $100 \mu \mathrm{L}$ of each standard and sample was added into appropriate wells. The wells were covered and incubated for 150 minutes at room temperature. The solutions were discarded and washed 4 times, by filling each well with $1 \mathrm{X}$ wash solution $(300 \mu \mathrm{L})$ using a multi-channel pipette. Supernatant was completely removed at each step. After the last wash, any remaining wash buffer was removed by decanting and the plate was blotted against clean paper towels. Then, $100 \mu \mathrm{L}$ of $1 \mathrm{X}$ biotinylated TNF- $\alpha$ detection antibody was added to each well and incubated for 60 minutes at room temperature with gentle shaking. The solution was decanted and the wash was repeated. Then, $100 \mu \mathrm{L}$ of $1 \mathrm{X}$ HRPStreptavidin solution was added to each well. The plate was incubated for 45 minutes at room temperature with gentle shaking. The solution was decanted and the wells were washed. Then, $100 \mu \mathrm{L}$ of TMB one-step substrate reagent was added to each well and incubated for 30 minutes at room temperature in the dark with gentle shaking, and $50 \mu \mathrm{L}$ of stop solution was added to each well. The wells were read at $450 \mathrm{~nm}$. A standard curve was constructed for each method using the respective standard and used for the determination of unknown respective serum sample concentrations of IL-6, IL-8 or TNF- $\alpha$.

\section{Serum nitric oxide (NO) determination}

Nitric oxide concentration was determined using Griess reagent (Sulpanilamide and N-1-napthyethylenediamine dihydrochloride) as previously described. ${ }^{38}$ The assay was based on a reaction that utilized sulpanilamide and N-1-napthyethylenediamine dihydrochloride (NED) under acidic (phosphoric acid) conditions. Nitrite forms colored chromophore with reagent, with an absorbance spectrum maximum at $540 \mathrm{~nm}$. The production of nitrite was quantified by comparing the result with absorbance of standard solutions of sodium nitrite.

Serum hydrogen peroxide determination

Hydrogen peroxide concentration was determined as previously carried out. The assay was based on peroxide-mediated oxidation of $\mathrm{Fe}^{2+}$, followed by the reaction of $\mathrm{Fe}^{3+}$ with Xylenol orange to form $\mathrm{Fe}^{3+}$ Xylenol orange complex with an absorbance maximum of 560nm. Plasma $\mathrm{H}_{2} \mathrm{O}_{2}$ was determined by comparing absorbance with standard solutions of $\mathrm{H}_{2} \mathrm{O}_{2}$.

Serum myeloperoxidase (MPO) activity determination

MPO activity was determined as previously carried out. ${ }^{39}$ The rate of decomposition of $\mathrm{H}_{2} \mathrm{O}_{2}$ by peroxidase, with guaiacol as hydrogen donor, produced tetraguaiacol which was measured at $436 \mathrm{~nm}$ and at $25^{\circ} \mathrm{C}$.

Vitamin determinations

Vitamins B6, B12, folic acid and homocysteine were determined using Enzyme Linked Immunosorbent assay (ELISA) method as previously carried out. $^{38,39}$

\section{Statistical analysis}

Data obtained were analyzed using SPSS version 20, which are presented in the Tables as Means and Standard error of means. The data were evaluated using Student $t$-test for the patient group relative to the control group (Table 1) while Analysis of Variance (ANOVA) was used to compare data between the three groups of breast cancer patients. Student $t$-test was used to compare data between two groups of breast cancer patients in Tables 2, 3, Figures $1,2,3$ and 4 . $\mathrm{P} \leq 0.05$ was taken as significant.

\section{RESULTS}

The mean values and statistical comparison of TNF- $\alpha$, IL-6, IL-8, MPO, NO and $\mathrm{H}_{2} \mathrm{O}_{2}$ in breast cancer patients and the control group are presented in Table 1 . As the results show, the mean values of IL-6 ( $\mathrm{P}=0.002)$, IL-8 $(\mathrm{P}=0.018)$ and $\mathrm{H}_{2} \mathrm{O}_{2}(\mathrm{P}=0.000)$ were significantly increased while TNF- $\alpha(\mathrm{P}=0.014)$ and $\mathrm{NO}$ $(\mathrm{P}=0.044)$ were significantly decreased when breast cancer patients were compared with apparently healthy controls. However, there were no statistically significant differences in the levels of MPO, Zn, homocysteine, vitamin B6 and vitamin B12 when breast cancer patients were compared with controls (Table 1). Further, there were no statistically significant differences in the values of inflammation factors (Table 2) and micronutrients (Table 3) when breast cancer patients with different immunohistochemical hormonal status were compared or when breast cancer patients with double positives, single positive or no hormonal receptors were compared (Figures 1 and 2). There were no statistically significant differences in the values of inflammation factors and micronutrients when breast cancer patients with different receptors were compared (Figures 3 and 4). 
Table 1. Comparison (Mean \pm SEM) of inflammation biomarkers and micronutrients in breast cancer patients and controls.

\begin{tabular}{lcccc}
\hline Inflammation biomarkers & BCa $(\mathrm{n}=80)$ & Controls $(\mathrm{n}=35)$ & t-values & $0.000^{*}$ \\
\hline $\mathrm{H}_{2} \mathrm{O}_{2}(\mu \mathrm{mol} / \mathrm{L})$ & $37.98 \pm 1.64$ & $18.18 \pm 1.27$ & 9.521 & 3.305 \\
$\mathrm{IL}-6(\mathrm{pg} / \mathrm{mL})$ & $31.72 \pm 6.10$ & $11.54 \pm 0.37$ & 2.438 & $0.002^{*}$ \\
$\mathrm{IL}-8(\mathrm{pg} / \mathrm{mL})$ & $29.65 \pm 2.48$ & $23.33 \pm 0.77$ & 2.507 & $0.018^{*}$ \\
$\mathrm{TNF}-\alpha(\mathrm{pg} / \mathrm{mL})$ & $7.96 \pm 1.24$ & $19.49 \pm 5.95$ & 2.046 & $0.014^{*}$ \\
$\mathrm{NO}(\mu \mathrm{mol} / \mathrm{L})$ & $25.32 \pm 2.48$ & $32.58 \pm 2.54$ & 0.695 & $0.044^{*}$ \\
$\mathrm{MPO}(\mathrm{U} / \mathrm{mL})$ & $1.15 \pm 0.20$ & $1.29 \pm 0.02$ & & 0.489 \\
\hline Micronutrients & & & 0.780 & 0.560 \\
\hline Zn $(\mu \mathrm{g} / \mathrm{dL})$ & $102.66 \pm 1.23$ & $104.49 \pm 2.00$ & 0.439 \\
$\mathrm{Hcy}(\mu \mathrm{mol} / \mathrm{L})$ & $12.69 \pm 0.54$ & $12.14 \pm 0.81$ & 0.568 & 0.570 \\
Folate $(\mu \mathrm{g} / \mathrm{L})$ & $348.51 \pm 14.76$ & $333.39 \pm 22.14$ & 0.570 & 0.572 \\
Vit B6 $(\mathrm{ng} / \mathrm{mL})$ & $15.86 \pm 0.67$ & $15.17 \pm 1.01$ & 0.416 & 0.578 \\
Vit B12 $(\mathrm{ng} / \mathrm{L})$ & $419.12 \pm 17.29$ & $405.73 \pm 26.95$ & & 0.677 \\
\hline
\end{tabular}

*Significant at $P<0.05$

$\mathrm{BCa}=$ Breast cancer, ER= Estrogen receptor, $\mathrm{PR}=$ Progesterone receptor, HER-2= Human Epidermal Growth Factor Receptor 2, Hcy= Homocysteine, $\mathrm{NO}=$ Nitric Oxide, $\mathrm{H}_{2} \mathrm{O}_{2}=$ Hydrogen peroxide, MPO= Myeloperoxidase, TNF- $\alpha=$ Tumor necrosis factor alpha, IL-6= Interleukin 6, Zn= Zinc, IL-8= Interleukin 8

Table 2. Comparison (Mean \pm SEM) of inflammation biomarkers in breast cancer patients with different immunohistochemical hormonal levels.

\begin{tabular}{lcccccc}
\hline & $\begin{array}{c}\mathrm{H}_{2} \mathrm{O}_{2} \\
(\mu \mathrm{mol} / \mathrm{L})\end{array}$ & $\begin{array}{c}\mathrm{IL}-6 \\
(\mathrm{pg} / \mathrm{mL})\end{array}$ & $\begin{array}{c}\mathrm{IL}-8 \\
(\mathrm{pg} / \mathrm{mL})\end{array}$ & $\begin{array}{c}\text { TNF- } \alpha \\
(\mathrm{pg} / \mathrm{mL})\end{array}$ & $\begin{array}{c}\mathrm{NO} \\
(\mu \mathrm{mol} / \mathrm{L})\end{array}$ & $\begin{array}{c}\mathrm{MPO} \\
(\mathrm{U} / \mathrm{mL})\end{array}$ \\
\hline $\begin{array}{l}\text { ER+ve(n=17) } \\
\text { PR+ve (n=16) }\end{array}$ & $38.6 \pm 10.4$ & $26.6 \pm 9.4$ & $28.1 \pm 2.1$ & $8.1 \pm 1.5$ & $24.8 \pm 14.9$ & $1.0 \pm 0.3$ \\
$\begin{array}{l}\text { HER-2+ve } \\
\text { (n=16) }\end{array}$ & $35.8 \pm 14.0$ & $24.2 \pm 8.5$ & $27.3 \pm 3.7$ & $8.7 \pm 2.3$ & $31.9 \pm 32.2$ & $0.8 \pm 0.4$ \\
t, p-a & $0.415,0.686$ & $0.497,0.629$ & $0.498,0.628$ & $-0.564,0.584$ & $-0.527,0.609$ & $0.851,0.413$ \\
t, p-b & $0.807,0.437$ & $1.947,0.078$ & $-0.669,0.517$ & $0.424,0.680$ & $0.879,0.398$ & $0.017,0.987$ \\
t, p-c & $0.335,0.744$ & $1.475,0.171$ & $-0.713,0.492$ & $0.883,0.398$ & $0.982,0.349$ & $-0.769,0.460$ \\
\hline
\end{tabular}

a: ER+ve compared with PR+ve

b: ER+ve compared with HER-2+ve

c: PR+ve compared with HER-2+ve

ER=Estrogen receptor, PR=Progesterone receptor, HER-2=Human Epidermal Growth Factor Receptor 2, NO=Nitric Oxide, $\mathrm{H}_{2} \mathrm{O}_{2}=$ Hydrogen peroxide, MPO=Myeloperoxidase, TNF- $\alpha=$ Tumor necrosis factor alpha, IL-6=Interleukin 6, IL-8=Interleukin 8

Table 3. Comparison (Mean \pm SEM) of micronutrients in breast cancer patients with different immunohistochemical hormonal levels

\begin{tabular}{lccccc}
\hline & Zn $(\boldsymbol{\mu g} / \mathbf{d L})$ & Hcy $(\boldsymbol{\mu m o l} / \mathbf{L})$ & Folate $(\boldsymbol{\mu g} / \mathbf{L})$ & Vit B6 $(\mathbf{n g} / \mathbf{m L})$ & Vit B12 $(\mathbf{n g} / \mathbf{L})$ \\
\hline ER+ve $(\mathrm{n}=17)$ & $102.3 \pm 9.5$ & $11.3 \pm 4.2$ & $310.3 \pm 115.1$ & $14.1 \pm 5.2$ & $377.6 \pm 140.1$ \\
PR+ve (n=16) & $101.7 \pm 7.6$ & $12.4 \pm 3.7$ & $339.8 \pm 102.1$ & $15.5 \pm 4.6$ & $413.5 \pm 124.2$ \\
HER-2+ve (n=16) & $100.3 \pm 8.2$ & $12.5 \pm 5.2$ & $343.5 \pm 143.1$ & $15.6 \pm 6.5$ & $418.1 \pm 174.1$ \\
t, p-a & $0.131,0.898$ & $-0.485,0.637$ & $-0.485,0.637$ & $-0.485,0.637$ & $-0.485,0.637$ \\
t, p-b & $0.390,0.704$ & $-0.465,0.651$ & $-0.465,0.651$ & $-0.485,0.651$ & $-0.485,0.651$ \\
t, p-c & $0.287,0.780$ & $-0.052,0.960$ & $-0.052,0.960$ & $-0.052,0.960$ & $-0.052,0.960$ \\
\hline
\end{tabular}

a: ER+ve compared with PR+ve

b: ER+ve compared with HER-2+ve

c: PR+ve compared with HER-2+ve

ER=Estrogen receptor, PR=Progesterone receptor, HER-2=Human Epidermal Growth Factor Receptor 2, Hcy=Homocysteine, Zn=Zinc, Vit B6=Vitamin B6, Vit B12=Vitamin B12 

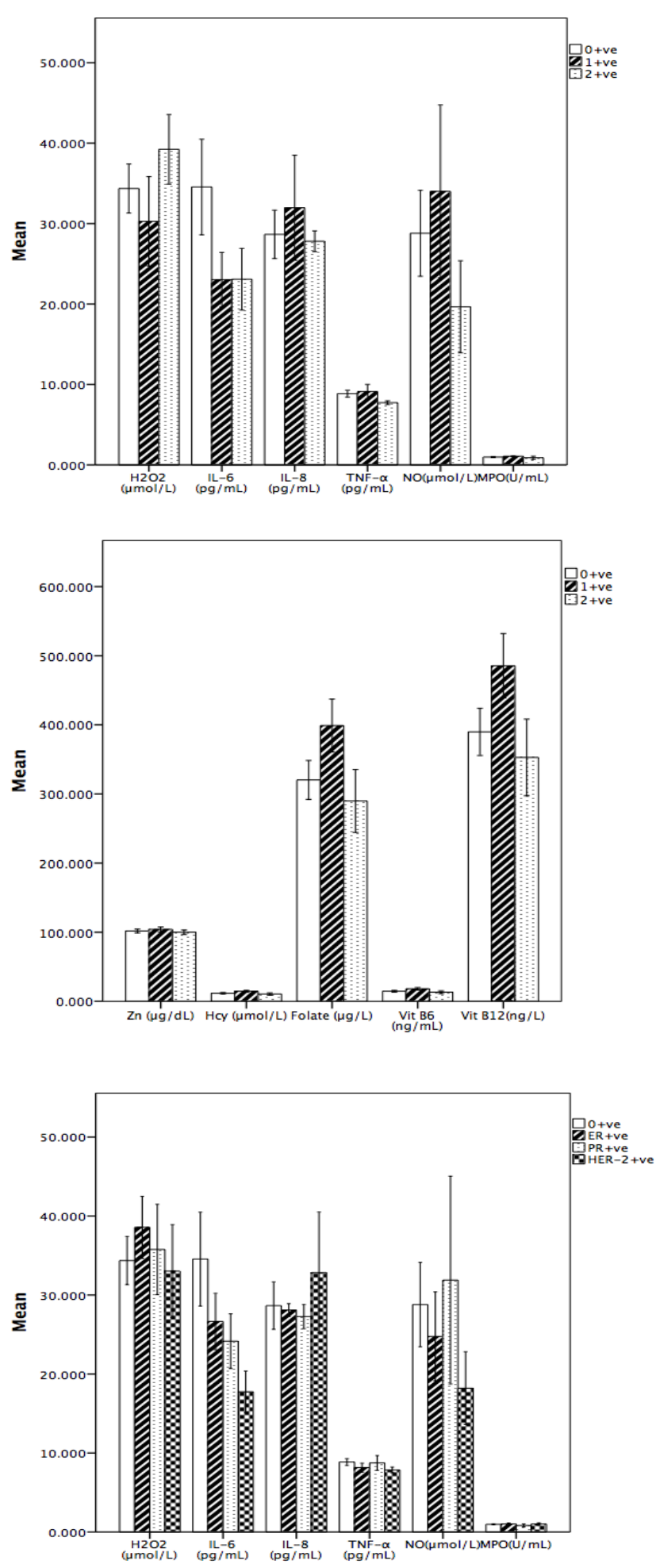

Figure 1. Inflammation biomarkers in breast cancer patients with double positives $(2+\mathrm{ve})$, single positive $(1+\mathrm{ve})$ or no $(0+\mathrm{ve})$ hormonal receptor.

$\mathrm{NO}=$ Nitric Oxide, $\mathrm{H}_{2} \mathrm{O}_{2}=$ Hydrogen peroxide, $\mathrm{MPO}=$ Myeloperoxidase, TNF- $\alpha=$ Tumor necrosis factor alpha, IL6=Interleukin 6, IL-8=Interleukin 8

Figure 2. Micronutrients in breast cancer patients having double positives (2+ve), single positive (1+ve) or no $(0+v e)$ hormonal receptor.

Hcy=Homocysteine, Zn=Zinc, Vit B6=Vitamin B6, Vit B12=Vitamin B12

Figure 3. Inflammation factors in breast cancer patients having HER-2+ve, ER+ve, PR+ve with no (0+ve) hormonal receptor.

$\mathrm{ER}=$ Estrogen receptor, $\mathrm{PR}=$ Progesterone receptor, HER2=Human Epidermal Growth Factor Receptor 2, Hcy=Homocysteine, NO=Nitric Oxide, $\mathrm{H}_{2} \mathrm{O}_{2}=$ Hydrogen peroxide, MPO=Myeloperoxidase, TNF- $\alpha=$ Tumor necrosis factor alpha, IL-6=Interleukin 6, IL-8=Interleukin 8 


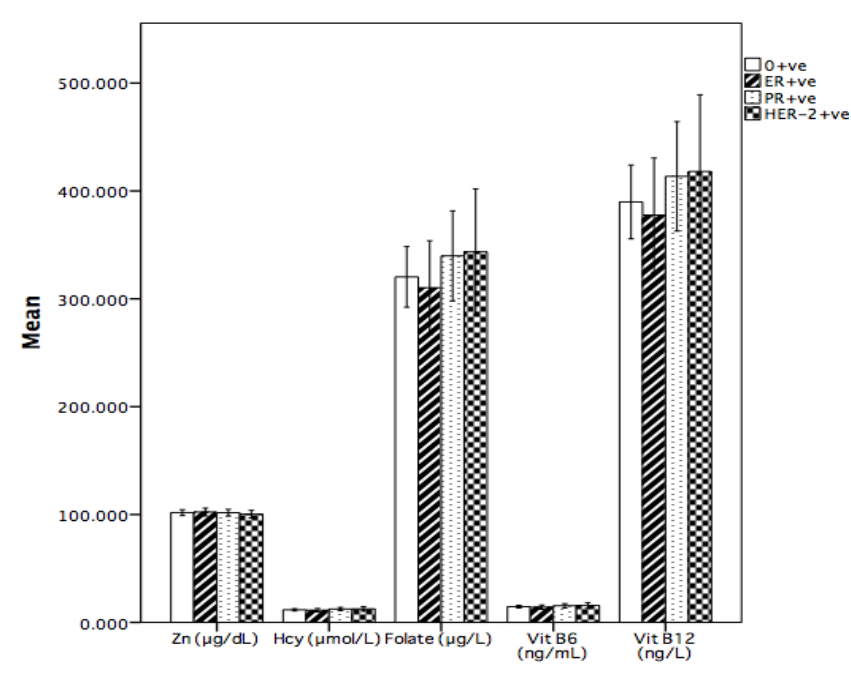

DISCUSSION

Globally, breast cancer constitutes a large public health burden among females and is often associated with inflammation. Studies elsewhere proposed the use of non-steroidal anti-inflammatory drugs such as aspirin in cancer prevention and as adjuvant therapies ${ }^{4,5}$ or use of micronutrients in reducing cancer progression. ${ }^{6}$ Other studies found inverse correlation between high intake or blood level of folate, vitamin B6, and vitamin B12 and risk of breast cancer ${ }^{18-21,40}$ while the studies associating circulating homocysteine with breast cancer risk are limited and with inconsistent result. ${ }^{9}$ However, the bases of earlier propositions linking serum inflammation factors or micronutrient status with breast cancer hormonal types have not been completely established. This study provides additional insight into the complex role of systemic inflammation and micronutrients involved in DNA methylation pathway in breast cancer etiology and progression.

The present study observed that serum levels of $\mathrm{H}_{2} \mathrm{O}_{2}$, IL-6 and IL-8, which drive inflammation were elevated in women with breast cancer relative to control subjects. Therefore, control of inflammatory process might have a complementary role in the management of breast cancer patients. EsquivelVelázquez et al. earlier reported that over-production of certain pro-inflammatory cytokines in breast cancer patients correlated with poor prognosis. ${ }^{41}$ Serum IL-6 and IL-8 have been implicated in the initiation and progression of ductal carcinoma. ${ }^{42-47}$ Our finding of increased IL-8 in breast cancer patients support previous reports that IL-8 is a chemokine that has tumor-promoting role and cancer predictive potential. ${ }^{44,}{ }^{45}$ Angiogenesis is an important step in metastasis in which IL-8 plays a critical role. ${ }^{48}$ Increased serum IL-8 in our breast cancer patients supports its functions in angiogenicity, neovascularization and increased propensity for metastasis as earlier studies suggested. ${ }^{44,45,48}$ Derin et
Figure 4. Micronutrients in breast cancer patients having HER-2+ve, ER+ve, PR+ve with no (0+ve) hormonal receptor.

$\mathrm{ER}=$ Estrogen receptor, $\mathrm{PR}=$ Progesterone receptor, HER-2=Human Epidermal Growth Factor Receptor 2, Hcy=Homocysteine, Zn=Zinc, Vit B6=Vitamin B6, Vit B12=Vitamin B12

al. reported high expression of IL-8 receptors on all breast cancer cells; thus, increased IL-8 in the breast cancer patients might be in response to overexpressed IL-8 receptors on breast cancer cells which accelerate angiogenesis. ${ }^{49}$ Thus, our data support the use of IL-8 antagonist as a plausible complementary option in the management of breast cancer patients. ${ }^{48,}$ 49

Numerous cytokines, such as IL-6, IL-8 and TNF$\alpha$ have been implicated in the initiation and progression of ductal carcinoma. ${ }^{42-49}$ IL-6 is a pro-inflammatory cytokine that has multiple functions such as regulation of immune functions and hematopoiesis, inhibition of apoptosis of cancer cells and stimulation of tumor angiogenesis. ${ }^{24}$ Serum IL-6 levels were increased in breast cancer patients which correlated with tumor stage and patient survival. ${ }^{12-16}$ Therefore, IL-6 has a tumor-promoting role with predictive cancer potential as earlier research pointed out. ${ }^{44}$

Granulocytes produce $\mathrm{H}_{2} \mathrm{O}_{2}$ via metabolic processes as an immunological response to foreign invaders. Hydrogen peroxide is catabolized to produce hypochlorous acid and hydroxyl radical. These highly reactive oxygen species have been reported to be effective in the killing of intracellular bacteria. ${ }^{6}$ Hydrogen peroxide at high concentrations causes membrane damage, increases lactate dehydrogenase leakage, membrane permeability or cell necrosis. ${ }^{50}$ A change in membrane permeability disturbs structural integrity, which could lead to the increased entry of toxins into cells and cause cell death at a later stage. Also, hydrogen peroxide has been reported to inactivate superoxide dismutase, which is an antioxidant. ${ }^{51}$ Therefore, increased blood levels of $\mathrm{H}_{2} \mathrm{O}_{2}$ might be responsible for gradual local tissue destruction or attempt to destroy invading micro-organisms in breast cancer patients.

Apart from its role in intracellular killing of pathogens and vascular smooth muscle relaxation, 
Nitric oxide (NO) modulates gene expression via the agency of transcription factors, especially Nuclear Factor- $\kappa \mathrm{B}(\mathrm{NF}-\kappa \mathrm{B})$, which regulates transcription of pro-inflammatory cytokines (IL-1 $\beta$, TNF- $\alpha$, IL-6 and IL-8) and enzyme (COX-2). ${ }^{52}$ In this present study, serum concentration of NO in breast cancer patients was significantly decreased when compared with controls. This might be one of the mechanisms to reduce NO-induced inflammatory processes in breast cancer patients. Also, NO directly oxidizes DNA, resulting in mutagenic changes and damage to DNA repair proteins. ${ }^{53} \mathrm{NO}$ is produced by conversion of arginine to citrulline using inducible nitric oxide synthase in phagocytes. Therefore, we speculated that low arginine level might account for decreased NO levels in breast cancer patients, but this requires further investigation.

Breast cancer is distinguished by different molecular subtypes, risk factors, clinical behaviors, and responses to treatment and steroid hormone receptors such as progesterone receptor (PR), estrogen receptor (ER) and human epidermal growth factor receptor 2 (HER-2) on tumors have been shown to play important roles in cancer progression and prognosis. ${ }^{54}$, 55 Whether there are relationships between the wide spectrum of serum inflammation factors, micronutrients and immunohistochemistry status of breast cancer patients has not been fully addressed.

\section{REFERENCES}

1. Lan T, Wang L, Xu Q, Liu W, Jin H, Mao W, et al. Growth inhibitory effect of Cucurbitacin E on breast cancer cells. Int J Clin Exp Pathol. 2013;6(9):1799.

2. Jemal A, Siegel R, Xu J, Ward E. Cancer statistics, 2010. CA Cancer J Clin. 2010;60(5):277-300.

3. Xuan C, Shamonki J, Chung A, Dinome M, Chung M, Sieling $\mathrm{P}$, et al. Microbial dysbiosis is associated with human breast cancer. PLoS One. 2014;9(1).

4. Cuzick J, Otto F, Baron J, Brown P, Burn J, Greenwald P, et al. Aspirin and non-steroidal antiinflammatory drugs for cancer prevention: an international consensus statement. Lancet Oncol. 2009;10(5):501-7.

5. Bosetti C, Gallus S, La Vecchia C. Aspirin and cancer risk: an updated quantitative review to 2005. Cancer Causes Control. 2006;17(7):871-88.

6. Arinola O, Charles-Davies M. Micronutrient levels in the plasma of Nigerian females with breast cancer. African J Biotechnol. 2010;7(11):1620-3.

7. Marzo AM De, Platz EA, Sutcliffe S, Xu J, Grönberg $\mathrm{H}$, Drake CG, et al. Inflammation in prostate carcinogenesis. Nat Rev Cancer. 2007;7(4):256.
Furthermore, expressions of ER, PR and HER-2 in breast carcinoma patients were found to correlate with prognosis. $^{.6-59}$ This necessitates linking proinflammatory biomarkers with ER, PR or HER-2 expressions in Nigerian breast cancer patients.

\section{CONCLUSION}

In the present study, there were no differences in the levels of serum inflammation biomarkers and micronutrient levels in Nigerian breast cancer patients relative to ER, PR or HER-2 expression. The authors of the present study speculated that cytokine production and micronutrient status were not affected by ER, PR or HER-2 expression. However, recruitment of larger participants will further elucidate this conjecture. A key limitation of this study was the small number of breast cancer patients with different hormonal immunohistochemistry statuses.

\section{CONFLICT OF INTEREST}

None.

\section{ACKNOWLEDGEMENTS}

This study was partly sponsored by D43 NIH Reentry Grant given to GOA through NIH Training Grant awarded OFO and COO.

8. Elkahwaji JE. The role of inflammatory mediators in the development of prostatic hyperplasia and prostate cancer. Res Reports Urol. 2013;5(1):1.

9. Zhang S, Willett W, Selhub J, Hunter D, Giovannucci E, Holmes M, et al. Plasma folate, vitamin B6, vitamin B12, homocysteine, and risk of breast cancer. J Natl Cancer Inst. 2003;95(5):373-80.

10. Finkelstein J. Methionine metabolism in mammals. J Nutr Biochem. 1990;1(5):228-37.

11. Sun C, Haven T, Wu T, Tsao K, Wu J. Serum total homocysteine increases with the rapid proliferation rate of tumor cells and decline upon cell death: a potential new tumor marker. Clin Chim Acta. 2002;321(1-2):55-62.

12. Wu L, Wu J. Hyperhomocysteinemia is a risk factor for cancer and a new potential tumor marker. Clin Chim Acta. 2002;322(1-2):21-8.

13. Hogg N. The effect of cyst(e)ine on the autooxidation of homocysteine. Free Radic Biol Med. 1999;27(1-2):28-33.

14. Stipanuk M. Sulfur amino acid metabolism: pathways for production and removal of homocysteine and cysteine. Annu Rev Nutr. 2004;24:539-77. 
15. Chou Y, Lee M, Wu M, Shih H, Yang T, Yu C, et al. Plasma homocysteine as a metabolic risk factor for breast cancer: findings from a case-control study in Taiwan. Breast Cancer Res Treat. 2007;101(2):199205.

16. Mason JB, Levesque T. Folate: effects on carcinogenesis and the potential for cancer chemoprevention. Oncology (Williston Park). 1996;10(11):1727-1736,1742-1744.

17. Ames B. DNA damage from micronutrient deficiencies is likely to be a major cause of cancer. Mutat Res. 2001 Apr 18;475(1-2):7-20.

18. Giovannucci E. Epidemiologic studies of folate and colorectal neoplasia: a review. J Nutr. 2002;132(8 Suppl).

19. Larsson S, Giovannucci E, Wolk A. Folate and risk of breast cancer: a meta-analysis. J Natl Cancer Inst. 2007;99(1):64-76.

20. Lin J, Lee I, Cook N, Selhub J, Manson J, Buring J, et al. Plasma folate, vitamin B-6, vitamin B-12, and risk of breast cancer in women. Am J Clin Nutr. 2008;87(3):734-43.

21. Wei E, Giovannucci E, Selhub J, Fuchs C, Hankinson S, Ma J. Plasma vitamin B6 and the risk of colorectal cancer and adenoma in women. J Natl Cancer Inst. 2005;97(9):684-92.

22. Brieger A, Rink L, Haase H. Differential Regulation of TLR-Dependent MyD88 and TRIF Signaling Pathways by Free Zinc Ions. J Immunol. 2013;191(4):1808-17.

23. Summersgill H, England H, Lopez-Castejon G, Lawrence C, Luheshi N, Pahle J, et al. Zinc depletion regulates the processing and secretion of IL-1 $\beta$. Cell Death Dis. 2014;5(1).

24. Mayer L, Uciechowski P, Meyer S, Schwerdtle T, Rink L, Haase H. Differential impact of zinc deficiency on phagocytosis, oxidative burst, and production of pro-inflammatory cytokines by human monocytes. Metallomics. 2014;6(7):1288-95.

25. Gupta S, Shukla V, Vaidya M, Roy S, Gupta S. Serum trace elements and $\mathrm{Cu} / \mathrm{Zn}$ ratio in breast cancer patients. J Surg Oncol. 1991;46(3):178-81.

26. Adzersen K, Jess P, Freivogel K, Gerhard I, Bastert G. Raw and cooked vegetables, fruits, selected micronutrients, and breast cancer risk: a case-control study in Germany. Nutr Cancer. 2003;46(2):131-7.

27. Garland M, Morris J, Colditz G, Stampfer M, Spate V, Baskett C, et al. Toenail trace element levels and breast cancer: a prospective study. Am J Epidemiol. 1996;144(7):653-60.

28. Cui Y, Vogt S, Olson N, Glass A, Rohan T. Levels of zinc, selenium, calcium, and iron in benign breast tissue and risk of subsequent breast cancer. Cancer Epidemiol Biomarkers Prev. 2007;16(8):1682-5.
29. Piccinini L, Borella P, Bargellini A, Medici C, Zoboli A. A case-control study on selenium, zinc, and copper in plasma and hair of subjects affected by breast and lung cancer. Biol Trace Elem Res. 1996;51(1):23-30.

30. Hammond M, Hayes D, Wolff A, Mangu P, Temin S. American society of clinical oncology/college of american pathologists guideline recommendations for immunohistochemical testing of estrogen and progesterone receptors in breast cancer. J Oncol Pract. 2010;6(4):195-7.

31. Sotiriou C, Pusztai L. Gene-expression signatures in breast cancer. N Engl J Med. 2009;360(8):790-800.

32. Kumar V, Abbas AK, Aster JC, Cotran RS. Robbins and Cotran Pathologic Basis of Disease. 2010. 1391 p.

33. Bingle L, Brown N, Lewis C. The role of tumourassociated macrophages in tumour progression: implications for new anticancer therapies. J Pathol. 2002;196(3):254-65.

34. Gordon S, Taylor PR. Monocyte and macrophage heterogeneity. Nat Rev Immunol. 2005;5(12):95364.

35. Mosser $\mathrm{D}$. The many faces of macrophage activation. J Leukoc Biol. 2003;73(2):209-12.

36. Verreck F, de Boer T, Langenberg D, Hoeve M, Kramer M, Vaisberg E, et al. Human IL-23-producing type 1 macrophages promote but IL-10-producing type 2 macrophages subvert immunity to (myco)bacteria. Proc Natl Acad Sci U S A. 2004;101(13):4560-5.

37. Ahmed HH, Metwally FM, Mahdy E-SM, Shosha WG, Ramadan SS. Clinical value of serum hepatocyte growth factor, B-cell lymphoma-2 and nitric oxide in primary breast cancer patients. Eur Rev Med Pharmacol Sci. 2012;16(7):958-65.

38. Arinola GO, Akinwande K. Cytokine Levels and Micronutrient Status in Ascaris lumbricoides Infected Nigerian School Children after Albendazole Treatment. Tanzania Med J. 2021;32(2):1-20.

39. Arinola GO, Edem FV. Antioxidant Vitamins Are Correlated with Different Aspects of Phagocytic Processes in Healthy Nigerians: Benefits As Supplements During Antimicrobial Treatment. Sudan J Med Sci. 2020 Sep 30;15(3):225-36.

40. Lin J, Lee I, Song Y, Cook N, Selhub J, Manson J, et al. Plasma homocysteine and cysteine and risk of breast cancer in women. Cancer Res. 2010;70(6):2397-405.

41. Esquivel-Velázquez M, Ostoa-Saloma P, PalaciosArreola M, Nava-Castro K, Castro J, Morales-Montor $\mathrm{J}$. The role of cytokines in breast cancer development and progression. J Interferon Cytokine Res. 2015;35(1):1-16.

42. Nariţa D, Seclaman E, Ursoniu S, Ilina R, Cireap N, 
Anghel A. Expression of CCL18 and interleukin-6 in the plasma of breast cancer patients as compared with benign tumor patients and healthy controls. Rom J Morphol Embryol. 2011;52(4):1261-7.

43. Alokail M, Al-Daghri N, Mohammed A, Vanhoutte P, Alenad A. Increased TNF $\alpha$, IL-6 and ErbB2 mRNA expression in peripheral blood leukocytes from breast cancer patients. Med Oncol. 2014;31(8):38.

44. Todorović-Raković N, Milovanović J. Interleukin-8 in breast cancer progression. J Interferon Cytokine Res. 2013;33(10):563-70.

45. Katanov C, Lerrer S, Liubomirski Y, Leider-Trejo L, Meshel T, Bar J, et al. Regulation of the inflammatory profile of stromal cells in human breast cancer: prominent roles for TNF- $\alpha$ and the NF- $\kappa$ B pathway. Stem Cell Res Ther. 2015;6(1):1-7.

46. Deshmukh SK, Srivastava SK, Bhardwaj A, Singh AP, Tyagi N, Marimuthu S, et al. Resistin and interleukin-6 exhibit racially-disparate expression in breast cancer patients, display molecular association and promote growth and aggressiveness of tumor cells through STAT3 activation. Oncotarget. 2015;6(13):11231.

47. Yao C, Lin Y, Chua M, Ye C, Bi J, Li W, et al. Interleukin-8 modulates growth and invasiveness of estrogen receptor-negative breast cancer cells. Int J cancer [Internet]. 2007 Nov 1 [cited 2021 Sep 20];121(9):1949-57.

48. Sheikhpour R. The Role of Interleukin-8 and Its Mechanism in Patients with Breast Cancer: Its Relation with Oxidative Stress and Estrogen Receptor. Int J Cancer Manag. 2017;10(9): e8791.

49. Derin D, Soydinc H, Guney N, Tas F, Camlica H, Duranyildiz D, et al. Serum IL-8 and IL-12 levels in breast cancer. Med Oncol. 2007;24(2):163-8.

50. Olopade C, Frank E, Bartlett E, Alexander D, Dutta A, Ibigbami $T$, et al. Effect of a clean stove intervention on inflammatory biomarkers in pregnant women in Ibadan, Nigeria: A randomized controlled study. Environ Int. 2017;98:181-90.
51. Nita M, Grzybowski A. The Role of the Reactive Oxygen Species and Oxidative Stress in the Pathomechanism of the Age-Related Ocular Diseases and Other Pathologies of the Anterior and Posterior Eye Segments in Adults. Oxid Med Cell Longev. 2016;2016.

52. Tang C-H, Wei W, Liu L. Regulation of DNA Repair by S-Nitrosylation. Biochim Biophys Acta. 2012;1820(6):730.

53. Izumi T, Wiederhold LR, Roy G, Roy R, Jaiswal A, Bhakat KK, et al. Mammalian DNA base excision repair proteins: Their interactions and role in repair of oxidative DNA damage. Toxicology. 2003;193(12):43-65.

54. Zhou X, Fan W, Yang G, Yu M. The clinical significance of PR, ER, NF- $\kappa \mathrm{B}$, and TNF- $\alpha$ in breast cancer. Dis Markers. 2014;2014.

55. Bhatia A, Sekhon HK, Kaur G. Sex Hormones and Immune Dimorphism. Sci World J. 2014;2014.

56. Al-Saleh K, Salah T, Arafah M, Husain S, Al-Rikabi A, El-Aziz NA. Prognostic significance of estrogen, progesterone and HER2 receptors' status conversion following neoadjuvant chemotherapy in patients with locally advanced breast cancer: Results from a tertiary Cancer Center in Saudi Arabia. PLoS One. 2021; 16(3):e0247802.

57. Parise C, Bauer K, Brown M, Caggiano V. Breast cancer subtypes as defined by the estrogen receptor (ER), progesterone receptor (PR), and the human epidermal growth factor receptor 2 (HER2) among women with invasive breast cancer in California, 1999-2004. Breast J. 2009;15(6):593-602.

58. Onitilo A, Engel J, Greenlee R, Mukesh B. Breast cancer subtypes based on ER/PR and Her2 expression: comparison of clinicopathologic features and survival. Clin Med Res. 2009;7(1-2):4-13.

59. Sinha S, Nath J, Mukherjee A, Chatterjee T. Predictive and Prognostic Factors in Breast Cancer and their Association with ER PR HER2/neu Expression. J Carcinog Mutagen. 2016;7(2):1-4.

\section{How to Cite This Article}

Arinola GO, Edem FV, Odetunde AB, Olopade CO, Olopade IO. Serum Inflammation Biomarkers and Micronutrient Levels in Nigerian Breast Cancer Patients with Different Hormonal Immunohistochemistry Status. Arch Breast Cancer. 2021; 8(4):329-337. Available from: https://www.archbreastcancer.com/index.php/abc/article/view/449 